\title{
Improvement of haemoglobin level through supplementation of raagi $L a d d u$, drumstick leaf powder and iron tablets among adolescent girls
}

\author{
M. BHAVYA MANJARI* AND C. PADMA VENI \\ Krishi Vigyan Kendra, Rudrur, NIZAMABAD (TELANGANA) INDIA
}

\begin{abstract}
The study was conducted on adolescent girls who had anemic clinical signs and supplemented raagi $L a d d u$, drumstick leaf powder and iron tablets for four months for improvement of hemoglobin under on farm testing for three years and one year front line demonstration at Krishi Vigyan Kendra, Rudrur, Nizamabad district Telangana state. The results revealed that there was no improvement in hemoglobin level for treatment normal diet only, for second treatment the hemoglobin level of the adolescent girls was below normal hemoglobin level but on an average $0.36 \mathrm{mg} /$ $\mathrm{dl}$ increased hemoglobin levels was observed after four months intervention. Other symptoms are proscribed and slight upgrading in weights of adolescent girls $3(17 \%)$ were in normal weight and $15(83 \%)$ in under weight. Adolescent girls had improved their mean hemoglobin level from $8.9 \mathrm{mg} / \mathrm{dl}$ to $9.5 \mathrm{mg} / \mathrm{dl}$ but their hemoglobin level was lower than the normal hemoglobin level. Though their BMI showed they were in underweight but the average BMI increased from 16 to 16.7 after four months.
\end{abstract}

KEY WORDS : Adolescent girls, Haemoglobin, Raagi Laddu, Drumstick leaf powder, Iron tablets, BMI

View Point Article : Manjari, M. Bhavya and Veni, C. Padma (2017). Improvement of haemoglobin level through supplementation of raagi Laddu, drumstick leaf powder and iron tablets among adolescent girls. Internat. J. Home Sci. Extn. \& Comm. Manage., 4 (2): 82-87. DOI : 10.15740/HAS/IJHSECM/4.2/82-87.

Article History : Received : 23.04.2017; Revised : 15.06.2017; Accepted : 26.06.2017

* Author for correspondence (Email : mbhavyamanjari@yahoo.com) 